\title{
MANAGEMENT AND SUPERVISION OF ZAKAT AT THE NATIONAL AMIL ZAKAT AGENCY (BAZNAS) OF BENGKULU PROVINCE IN 2019-2020
}

\author{
Mardhatillah Suaka, Mardenis, Zefrizal Nurdin \\ 1,2, 3 Pascasarjana Universitas Andalas \\ Jl. Pancasila No. 10 Kota Padang Sumatera Barat \\ Email: iilsuaka@gmail.com
}

\begin{abstract}
This study aims to determine the zakat collection, distribution of zakat, and supervision of BAZNAS Bengkulu Province. The research method used is a juridical empirical type by interviewing directly to the BAZNAS Bengkulu Province and the Bengkulu Provincial Government; after the data has been collected through the interview process, the data is qualitatively processed to explain and expand objective management and oversight of zakat without using the statistical formula. The results of this study (1) The collection of zakat assets is carried out in 3 stages. The planning stage is not carried out with a particular strategy. It is not fixed on a specific schedule, the coordinating stage is carried out directly and indirectly, and the implementation stage is sourced from individual zakat and business entity zakat. (2) Distribution of zakat assets is carried out in 3 stages, namely the planning stage, by forming six work programs. The coordinating stage is carried out by holding a Regional Coordination Meeting (Rakorda). The implementation stage is divided into two: distribution in the form of consumptive zakat distribution and utilization in the form of distribution zakat is productive. (3) Supervision of the BAZNAS Bengkulu Province is carried out internally by the leadership to its staff. External supervision is carried out by the Ministry of Religion, Public Accountants, and the community.
\end{abstract}

Keywords: BAZNAS; Bengkulu Province; Controlling; Management

Abstrak: Penelitian ini bertujuan untuk mengetahui pengumpulan dan penyaluran zakat, serta pengawasan terhadap BAZNAS Provinsi Bengkulu. Jenis penelitian ini bersifat empiris yuridis dengan cara wawancara langsung ke Kantor BAZNAS dan Pemerintah Daerah Provinsi Bengkulu. Setelah data terkumpul, data diproses secara kualitatif tanpa menggunakan rumus statistik. Hasil penelitian ini menunjukkan (1) Pengumpulan zakat harta dilakukan dengan 3 tahapan. Pada tahap perencanaan, tidak dilakukan dengan strategi khusus dan tidak ditetapkan pada jadwal tertentu, lalu tahap pengoordinasian pengumpulan zakat dilakukan secara langsung dan secara tidak langsung, dan tahap pelaksanaan pengumpulan zakat bersumber dari zakat perorangan dan zakat badan usaha. (2) Penyaluran zakat harta dilakukan dengan 3 tahapan yakni tahap perencanaan penyaluran zakat dengan cara membentuk 6 program kerja, tahap pengkordinasian penyaluran zakat dengan mengadakan Rapat Koordinasi Daerah (Rakorda), dan tahap pelaksanaan penyaluran zakat dengan pendistribusian zakat bersifat konsumtif dan pendayagunaan penyaluran zakat yang bersifat produktif. (3) Pengawasan terhadap BAZNAS Provinsi Bengkulu dilakukan secara internal oleh pimpinan kepada stafnya, dan pengawasan secara eksternal dilakukan oleh Kementerian Agama, akuntan publik, dan masyarakat.

Kata kunci: BAZNAS; Provinsi Bengkulu; Pengawasan; Pengelolaan 


\section{Introduction}

Poverty has become a significant problem as if it will never be solved and continues to rise. Based on data from the World Bank's Annual Change in extreme poverty, Indonesia is the 11th poorest country of all countries in the world. ${ }^{1}$ As the religion of the majority Muslim population in Indonesia, Islam has solutions to address and help the poor. The solution to the problem of poverty in Islam is known as zakat. ${ }^{2}$ The obligation to pay zakat is mentioned approximately as many as 82 verses in the Qur'an. ${ }^{3}$

The obligation to pay zakat in the Qur'anic verse is often juxtaposed with the command of prayer. When praying is a form of individual communication to the Creator, zakat is likened to a form of human communication with other humans. ${ }^{4}$

Based on the pocketbook calculating zakat issued by the Directorate of Zakat Empowerment of the Ministry of Religious Affairs of the Republic of Indonesia in 2013, it was mentioned that zakat Divided into two types, namely zakat fitrah and zakat treasure. Zakat Fitrah is zakat that is required to

1 Herdaru Purnomo, "Top Pak Jokowi ! Perangi Kemiskinan Ekstrem, RI Masuk 15 Besar", diakses on 25 Februari 2021 dari https://www.cnbcindonesia. com/news/20191119085453-4-116192/top-pak-jokowiperangi-kemiskinan-ekstrem-ri-masuk-15-besar/2.

2 Muhyiddin Khotib, Rekonstruksi Fikih Zakat: Telaah Komprehensif Fikih Zakat Pendekatan Teoritis and Metodologi, (Malang: CV. Literasi Nusantara Abadi, 2019), p. 6.

${ }^{3}$ Siti Nurhasana, "Maksimalisasi Potensi Zakat melalui Peningkatan Kesadaran Masyarakat”, Jurnal Ekonomi and Bisnis Islam Jebi Fakultas Ekonomi and Bisnis Islam Universitas Islam Negeri Imam Bonjol Paandg, Vol. 3. Nomor 2 Tahun 2018 diakses dari http://journal.febi. uinib.ac.id/index.php/jebi/article/view/177/197.

4 Rachmat Hidajat, "Penerapan Manajemen Zakat Produktif dalam Meningkatkan Ekonomi Umat di PKPU (Pos Keadilan Peduli Umat) Kota Makasar" Jurnal Studi Agama, Vol. XVII, No.1 Tahun 2017 diakses dari https:// journal.uii.ac.id/Millah/article/view/10049 individuals to be distributed during the holy month of Ramadan. 5 While zakat property is the activity of issuing certain assets to the party entitled to receive on condition that the property has reached its nisab and ownership reaches a haul (even a matter of one year). ${ }^{6}$

When the requirements of zakat property have been fulfilled, the law is mandatory for someone to pay zakat. Although zakat is an individual obligation, the management of zakat should be regulated by the state, as exemplified by the Prophet, who was managed directly by the ruler at that time. To accommodate the management of zakat by the state, the government has established arrangements regarding zakat stipulated in Law No. 23 of 2011 on Zakat Management and Government Regulation No. 14 of 2014 on The Implementation of Zakat Management. The regulation divides the Zakat Management Organization into 2:

1. National Amil Zakat Agency (BAZNAS), which is a zakat management organization formed by the government.

2. Amil Zakat Institution (LAZ) is a zakat management organization formed by the community and for the community.

Based on the results of interviews in BAZNAS Bengkulu Province, most muzakis who pay zakat to BAZNAS only come from among the State Civil Apparatus (ASN) while muzaki who are in the private sector, only a handful pay zakat to BAZNAS.

The factor that causes the low collection of zakat through BAZNAS is due to the assumption in the community that BAZNAS is less professional and not transparent in managing zakat. There is also a concern that BAZNAS is affiliated with the government

\footnotetext{
${ }^{5}$ Sri Nurhayati, Akutansi and Manajemen Zakat, (Jakarta Selatan: Salemba Empat, 2019), p. 16.

${ }^{6}$ Sri Nurhayati, Akutansi and Manajemen..., p. 17
} 
for political purposes that have a negative image. Educational factors are also the cause of the community not paying zakat through BAZNAS. As a result, most muzakis pay their zakat directly to mustahik. ${ }^{7}$

Supervision of zakat management in BAZNAS Bengkulu Province also does not work correctly. Supervision of zakat management is only carried out internally only by the chairman and vice-chairman of BAZNAS Bengkulu Province. While the supervision of zakat management externally should be carried out by public accountants and the Regional Government of Bengkulu Province has never been done since BAZNAS Bengkulu Province was established now ${ }^{8}$.

External supervision of zakat management in BAZNAS Bengkulu Province should be conducted financial audit by public accountants and sharia audit by the Ministry of Religious Affairs following Article 75 of Government Regulation No. 14 of 2014 on Implementation states:

1. Reports on the implementation of zakat, infak, alms, and religious, social funds must be conducted sharia and financial audits;

2. Sharia audit conducted by the ministry that organizes government affairs in the field of religion; and

3. Public accountants conduct financial audits.

Sharia audit evaluates whether the implementation of zakat fund management is following Islamic sharia or not. In comparison, the audit of the financial statements of zakat management is carried out by public accountants.

\footnotetext{
${ }^{7}$ Ermi Suhasti Syafe'i, Mengoptimalkan Potensi Zakat, (Yogyakarta: (P3EI) UII, 2002), p. 575.

8 Indria Fitri Afiyana, "Tantangan Pengelolaan...", p. 11.
}

BAZNAS Bengkulu Province needs audit of the financial statements of zakat management by public accountants to increase the trust of muzaki, who distributes zakat funds, and prevent amil zakat from committing irregularities, manipulation, or misappropriation of zakat management. However, until 2019, public accountants have never been partners in auditing the financial statements of zakat management by BAZNAS Bengkulu province.

The local Provincial Government should also carry out external supervision of zakat management and being carried out by public accountants. Supervision of zakat management by the Regional Government of Bengkulu Province was never implemented? Based on the background description of the above problem, it can be formulated research problems as follows:

1. How to collect zakat carried out by BAZNAS Bengkulu Province?

2. How is the distribution of zakat carried out by BAZNAS Bengkulu Province?

3. How to monitor zakat management carried out against BAZNAS Bengkulu Province?

\section{Research Methods}

This research is empirical juridical (field law research). This research is descriptive, meaning that researchers want to objectively portray the management and supervision of zakat in BAZNAS Bengkulu Province. The population in the study included all stakeholders related to the management and supervision of zakat in BAZNAS Bengkulu Province, while respondents using purposive sampling consisted of the chairman and vicechairman of BAZNAS Bengkulu Province, Chairman of BAZNAS Bengkulu City, Head

\footnotetext{
${ }^{9}$ Indria Fitri Afiyana, “Tantangan Pengelolaan...”, p. 12.
} 
of Social Welfare of Bengkulu Provincial Government, Head of Zakat and Waqf Of The Ministry of Religious Affairs of Bengkulu Province, and Head of Amil Zakat Institution in Bengkulu Province.

\section{Theory of Zakat}

\section{Zakat Collection}

a. Zakat Fitrah

Zakat fitrah (zakat al-fitr) is the zakat of the soul that must be paid by everyone who can afford it (including newborn babies) in the month of Ramadan. Understanding zakat fitrah in Article 1 number 3 of The Minister of Religious Affairs Regulation No. 52 of 2014 on The Terms and Procedures for Calculating Zakat Mal and Zakat Fitrah and Utilization of Zakat for Productive Business reads:

Zakat fitrah is the zakat of the soul that is obligatory upon every Muslim who lives in Ramadan.

Payment of zakat fitrah is made since the beginning of Ramadan and no later than the implementation of Eid prayers. The payment of zakat fitrah is in the form of money equivalent to 1 sha' food price, if converted in 2021 amounting to $\mathrm{Rp}$ $40,000,-{ }^{10}$

\section{b. Zakat Treasure}

Zakat Treasure (zakat mal) is the zakat of a person's wealth or legal entity on the condition that the property has reached its nisab, and its ownership reaches a haul (even a matter of one year) ${ }^{11}$.

Nisab is the determination of the limit of the least amount of property that must be

\footnotetext{
10 Admin BAZNAS, "Zakat Fitrah" diakses on 7 Agustus 2021 dari https://bengkulu.baznas.go.id/produk/ detail/zakat-fitrah.

${ }^{11}$ Sri Nurhayati, Akutansi and Manajemen..., p. 16.
}

issued zakat, as explained in MUI Fatwa No. 3 of 2003, Ijtima Ulama No. 4 of 2018, and Supreme Court Regulation No. 31 of 2018 essentially mention zakat income of a person calculated as much as 85 grams of gold and haul as a determination of the time limit of zakat required property. If nisab has been fulfilled as much as 85 grams, then the nisab must be issued zakat if the property has been owned for one year.

There is no detailed provision in the Qur'an on what property should be issued zakat, in contrast to the mustahik group mentioned in detail in Surat AT-Taubah verse 60 . Therefore, there are several zakat treasured objects: zakat profession, zakat jewelry, zakat productive property, zakat company, zakat trade, zakat livestock and fisheries, zakat agriculture and plantation, zakat mining, zakat shares, and zakat bonds shari'ah or sukuk.

\section{Distribution of Zakat}

a. Distribution of Consumptive Zakat

Consumptive zakat distribution means the distribution of zakat to meet daily mustahik life such as food, clothing, or other primary needs. The distribution of consumptive zakat does not educate mustahik because it can only be used once or consumable.

Consumptive zakat distribution gives fish to mustahik, but unfortunately, does not teach how to get the fish. While productive zakat is likened to providing nets to get fish, it is expected that mustahik waits for zakat and tries to meet his personal life needs.

b. Distribution of Productive Zakat

The distribution of productive zakat means the distribution of zakat to be managed back by mustahik for business capital or business development. Hopefully, the benefits of 
business capital can meet the needs of mustahik life.

In principle, the distribution of productive zakat is done so that mustahik can become muzaki. Such changes can occur when mustahik is allowed to manage a business or a specific skill that is then expected to change the life of the next mustahik.

\section{Supervision of Zakat Management Institutions}

The authority of supervision of zakat management agency (LPZ) is carried out by the Ministry of Religious Affairs, local government, and the community.

a. Ministry of Religious Affairs. The supervisory authority carried out by the Ministry of Religious Affairs against LPZ is based on Article 34 paragraph (1) of Law No. 23 of 2011 on Zakat Management, which reads: "The Minister carries out the construction and supervision of BAZNAS, BAZNAS Province, BAZNAS Regency/ City, and LAZ".

The Minister in charge of supervision of LPZ is the Minister of Religious Affairs through the Central Ministry of Religious Affairs of the Republic of Indonesia. The supervision carried out by the Ministry of Religious Affairs in the form of sharia audits is based on Article 75 of Government Regulation No. 14 of 2014, which reads: "Sharia audit is carried out by the ministry that organizes government affairs in the field of religion".

Sharia audit to evaluate whether the implementation of zakat fund management carried out by LPZ is by Islamic sharia or not as stipulated in Surat At-Taubah paragraph 60 .

b. Local government. The supervisory authority carried out by the local government against
LPZ is based on Article 34 paragraph (2) of Law No. 23 of 2011 on Zakat Management, which reads: "The Governor and regent/ mayor carry out the construction and supervision of BAZNAS Province, BAZNAS Regency/City, and LAZ by its authority".

The local government must supervise LPZ in the form of sharia audits, financial audits, and accountability for APBD funds. Supervision of sharia audit conducted by the local government to evaluate the distribution of zakat in its area, supervision of financial audits to evaluate the results of financial audits by public accountants, while supervision of the use of APBD funds is carried out as accountability of LPZ who have received zakat operational funds by the local government.

c. Community. The authority of supervision carried out by the community against LPZ is based on Article 35 paragraph (1) and (3) of Law No. 23 of 2011 on Zakat Management, which reads: "The community can participate in the construction and supervision of BAZNAS and LAZ". Supervision as referred to in paragraph (1) is carried out in the form of: a. Access to information about zakat management carried out by BAZNAS and LAZ, b. Delivery of information in case of irregularities in zakat management carried out by BAZNAS and LAZ.

The public has the right to supervise LPZ by looking for zakat management information that has been done by LPZ and then can report if LPZ carries out irregularities in zakat management to the local government and LPZ level above.

\section{Results and Discussions}

BAZNAS Provinsi Bengkulu merupakan badan resmi yang pimpinannya diangkat lima 
tahun sekali oleh Gubernur Provinsi Bengkulu. Berdasarkan Surat Keputusan (SK) Gubernur Nomor 179 Tahun 2016 tentang Pimpinan Badan Amil Zakat Nasional (BAZNAS) Provinsi Bengkulu Periode 2016-2021 terdiri dari:

Head : Drs. H. Mukhtaridi B, M.M.

Vice Head I : H.M. Ihsan Nasution, S.H.

Vice Head II : H. M, Syamlan, L.C.

Vice Head III: Indra Utama, S.E., M.M.

The Decree of Appointment of the Provincial BAZNAS Leadership is the attribution authority obtained by the Governor of Bengkulu Province through the principle of deconcentration. The authority of the Governor of Bengkulu Province in appointing zakat leadership is due to zakat being part of religious affairs. In contrast, religious affairs are part of the affairs of abslout government. ${ }^{12}$ BAZNAS Bengkulu Province only collects zakat treasure, while the collection of zakat fitrah is handed over to the committee of mosques in their respective areas during Ramadan. ${ }^{13}$

\section{Zakat Collection in BAZNAS Bengkulu Province}

Zakat collection in BAZNAS Bengkulu Province is divided into 3 stages: planning, coordinating, and implementation.

First, the planning stage. The zakat collection plan in BAZNAS bengkulu province is not done with a particular strategy and is not fixated on a specific schedule. However, it is done as needed and can be implemented at any time. The zakat collection plan carried out so far is directed to individuals and business entities.

\footnotetext{
12 Pasal 10 ayat (1) Unandg-Unandg Nomor 23 Tahun 2014 tentang Pemerintahan Daerah.

${ }^{13}$ Interviewed with Bunafi, as Kepala Pelaksana Baznas Provinsi at 14.00 on 19 Januari 2021.
}

The plan of collecting zakat to individuals is carried out through electronic media and lectures. The plan of collecting zakat through lectures by giving a mandate to some ustadz to distribute zakat obligations and inform the priority of paying zakat through BAZNAS Province either at the time of tabligh akbar or Friday sermon at Baitul Izzah Grand Mosque in Bengkulu City. Zakat collection plan is also carried out through electronic media by making an application to Radio Republik Indonesia (RRI), TVRI Bengkulu, and The People of Bengkulu TV to socialize the priority of paying zakat through BAZNAS, this is necessary because there are still many people who do not know and are not aware of the obligation to pay zakat for a Muslim. ${ }^{14}$

The zakat collection plan is intended for business entities and government agencies by socializing to business entities and government agencies that have not been formed Zakat Collection Unit (UPZ). ${ }^{15}$ The socialization plan for the formation of UPZ is carried out at any time as needed to equalize free time between BAZNAS Bengkulu Province with related business entities and government agencies. ${ }^{16}$ While in 2020, BAZNAS Bengkulu Province did not plan the socialization of the formation of UPZ due to the spread of the Covid-19 outbreak. ${ }^{17}$

Second, the level of coordination. The stage of coordinating zakat collection is divided into two, namely the collection of zakat directly and indirectly. The zakat collection is done by depositing zakat money directly to the Baznas Provincial office individually and zakat pick-

${ }^{14}$ Interviewed with Bunafi, at 14.00 on 19 Januari 2021.

15 Pasal 9 Unandg-Unandg Nomor 23 Tahun 2011 tentang Pengelolaan Zakat

${ }^{16}$ Interviewed with Bunafi, at 14.00 on 19 Januari 2021.

${ }^{17}$ Interviewed with Bunafi, at 14.00 on 19 Januari 2021. 
up media that BAZNAS Bengkulu Province has provided. While coordinating zakat collection is indirectly done through UPZ, bank accounts, and other payment methods:

a. The determination of the area of the establishment of UPZ has been regulated in Article 4 of the National Amil Zakat Agency Regulation No. 2 of 2016 on the Establishment and Working Arrangement of Zakat Collection Unit junto Article 54 of Government Regulation No. 14 of 2014 on the Implementation of Law No. 23 of 2011 on Zakat Management, namely: Vertical business entity office, Office of regional device work unit/ provincial regional institution, Provincial Owned Enterprises, Provincial-scale Private Companies, Universities, High Schools and Grand Mosques.

The coordination of zakat collection between BAZNAS Bengkulu Province and BAZNAS Kota does not overlap because it has been regulated in the Regulation of the Reva Agency as the field of collection of Zakat Indonesia Initiative (IZI) representative of Bengkulu Amil Zakat Nasional Number 2 of 2016 concerning the Establishment and Working Arrangement of Zakat Collection Unit. The coordination of zakat collection between BAZNAS Bengkulu Province and Amil Zakat Institution (LAZ) in Bengkulu City also does not overlap, as stated, namely:

In the collection, IZI does not take the land collection of zakat BAZNAS Bengkulu Province. IZI is only focused on collecting zakat for private companies and traders in Bengkulu City. ${ }^{18}$

All zakat collections conducted by BAZNAS Kota Bengkulu and Amil Zakat Institution

\footnotetext{
${ }_{18}$ Interviewed with Reva as Bidang Penghimpunan IZI Perwakilan Bengkulu at 11.00 on 29 Mei 2021.
}

(LAZ) are reported every 6 months to BAZNAS Bengkulu Province.

b. The collection of zakat indirectly can also be done by converting to baznas provincial bank account number (ATM service, bank counter, and mobile banking payment), such as: Bank Bengkulu 0010110017861, Bank Muamalat 4310017364, and BNI Syari'ah 1001002067. For parties who have transferred, it is expected to confirm to 089518581700 (WA).

c. BAZNAS Bengkulu Province also receives zakat through other payment media such as: OVO, Gopay, Link Aja, Shopee Pay, and Dana. All accounts are a.n BAZNAS Bengkulu Province and after transfer to the account is expected confirmation to number 089518581700 (WA).

Third, the implementation stage. There are many zakat treasures that are the object of zakat as stipulated in The Minister of Religious Affairs Regulation No. 52 of 2014 consisting of zakat income, zakat jewelry, zakat of productive property, zakat of companies, zakat of trade, zakat of livestock, zakat fishery, zakat agriculture, zakat of plantation, zakat mining, zakat of shares, and zakat bonds. In fact, the object of zakat that was successfully collected by BAZNAS Province until 2020 is only in the form of individual zakat from zakat income and zakat of business entities from profits.

\section{a. Individual zakat}

Individual zakat collected by BAZNAS Province consists of individual zakat derived from ASN and non-ASN salaries. The collection of zakat from individual zakat ASN and pe-gadget regional companies in BAZNAS Bengkulu Province is a top priority, because in baznas financial statements of Bengkulu Province in 2019 and 2020, 90\% 
(ninety percent) of zakat funds collected come from zakat income of employees who work in government agencies and regional companies.

The collection of zakat income from the category of work in a government agency is the majority of zakat collection in BAZNAS Bengkulu Province after the Governor's Circular Letter No. 451.1/248/B.1/2019 on Zakat Profession or Results in Bengkulu Province which contains:

Appealed to the Head of Regional Devices, Head of Vertical Agencies, and Head of Higher Education Institutions/BUMN/ BUMD and Private Companies/Professional Organizations in Bengkulu Province to collect zakat funds of their employees through UPZ which has been formed BAZNAS Bengkulu Province.

The zakat collection circular, which the Governor of Bengkulu Province formed, explained that collecting zakat income through UPZ formed by BAZNAS bengkulu province is essential and urgent to help the poor and poor in Bengkulu Province. The Governor's Circular Letter refers to Presidential Instruction No. 3 of 2014 on Optimization of Zakat Collection in Ministries/Institutions, Secretariat of State Institutions, Secretary General of State Commissions, Local Governments, SOEs and BUMD junto Circular Letter of the Minister of Home Affairs Number 450.12/3302/SJ dated June 30, 2014 on Optimization of Zakat Collection.

Meanwhile, the collection of zakat income that does not get special attention and seems ignored by BAZNAS Bengkulu Province is zakat income from employees who work in private companies and zakat income from professional work lawyers, doctors, and notaries. However, their revelations are not denied there is already included as obligatory zakat.
The implementation of zakat collection in the government agency environment carried out by BAZNAS Bengkulu Province by forming a Zakat Collection Unit (UPZ) as an extension of BAZNAS Provincial hand in collecting zakat funds. The UPZ has the right to collect zakat from employees who work in their respective business entities by filling out a form of payment of the amount of zakat funds that can be directly deducted by the agency's treasurer when receiving salaries every month. ${ }^{19}$

The affidavit is a binder for UPZ to cut employee salaries every month directly. In addition, the statement of employee salary deduction for zakat is also valid at UPZ University of Bengkulu. ${ }^{20}$ Unlike the UPZ in the Ministry of Religious Affairs of Bengkulu Province, its employees are not allowed to determine the amount of money that will be increased, but rather a letter of willingness to cut their salaries by 2.5 percent (no less and no more) by the Treasurer of the Ministry of Trade of Bengkulu Province. ${ }^{21}$

Zakat income collected by UPZ is deposited through baznas account of Bengkulu province or can come directly to baznas office of Bengkulu province. Regarding the time of depositing zakat money that has been collected by each agency differently, there is a UPZ that deposits the amount of zakat collected every month. However, there are also those who deposit zakat to BAZNAS Bengkulu Province after collecting several months. ${ }^{22}$ The amount of zakat income collected by

\footnotetext{
${ }^{19}$ Interviewed with Supardi Jaiz as Head of UPZ UIN Fatmawati Soekarno Bengkulu at 08.00 on 22 April 2021.

20 Interviewed with Wiryono as Head of UPZ Universitas Bengkulu Bengkulu at 11.00 on 24 April 2021.

${ }^{21}$ Interviewed with Septi as Secretary of Penaizawa Kanwil Kemenag Provinsi Bengkulu at 13.00 on 30 April 2021.

${ }^{22}$ Financial reports of BAZNAS, op.cit.
} 
BAZNAS bengkulu province through UPZ in government agencies in 2019 amounted to $\mathrm{Rp}$ $4,185,800,083$, - and in 2020 amounted to Rp 5,156,442,725.23

Individual zakat derived from non-ASN is zakat that is handed over directly to the BAZNAS Office of Bengkulu Province without going through the Zakat Collection Unit (UPZ) in the agency, usually community leaders such as the Governor and Deputy Governor of Bengkulu Province, ustaz who have cooperated with BAZNAS, previous BAZNAS leaders, and employees in BAZNAS Bengkulu Province. Zakat of non-ASN individuals can also come from employees of State-Owned Enterprises (SOEs), Regional Owned Enterprises (BUMD), and private employees who already have the awareness of paying in the agency where they work there are no facilities for their employees to pay zakat. ${ }^{24}$

The amount of non-ASN individual zakat collected in 2019 was Rp 582,150,563, - from 142 people. Meanwhile, in 2020 amounted to Rp 149,450,973, - from 53 people. In 2020, the collection of individual zakat has caused sharp depreciation due to the impact of covid-19.25

\section{b. Zakat Business Entity}

Only a few business entities have been successfully collected zakat by BAZNAS Bengkulu Province, this is because zakat business entities are considered not religious affairs as stated by Bunafi as Head of Baznas Business Administration of Bengkulu Province, namely:

Zakat of the company collected is not zakat from corporate profits but zakat on behalf of

${ }^{23}$ Financial reports of BAZNAS Provinsi Bengkulu in 2019 and 2020.

${ }^{24}$ Interviewed with Bunafi, op.cit.

${ }^{25}$ Financial reports of BAZNAS Provinsi Bengkulu, op.cit. company owners, such as zakat AC Mobil and PT. Kartika Buana Rafflesia. ${ }^{26}$

Baznas zakat board of Bengkulu Province indirectly admits that the classification of zakat business entities made in the financial statements of zakat management is only a mere formality, because zakat is given on behalf of the owner. Zakat business entity is understood based on the understanding of zakat in Article 1 number 2 of the Zakat Management Act, which reads: "Zakat is a property that must be issued by a Muslim or business entity to be given to those who are entitled to receive it by Islamic sharia".

The connotation of "business entity" in the object of zakat collection is due in the subject of law known as natuurlijk person and rechtpersoon. Natuurlijk person refers to the subject of individual law and rechtpersoon refers to the subject of legal entity law. Therefore, zakat business entities are a result of the legal provisions that apply in Indonesia.

Although the obligation of zakat property in Surat At-Taubah paragraph 103 is only addressed to individuals to purify the soul of its owner, but for the sake of justice and expediency that will affect more people, zakat business entities should be implemented and launched in Bengkulu Province, especially companies whose shares are majority owned by Muslims. Decree of the Advisory Board of the National Amil Zakat Agency No:001/ DP-BAZNAS/XII/2010 on guidelines for the collection and administration of Zakat, Infaq, and Shadaqah at the National Amil Zakat Agency states:

"Zakat companies are only allowed for private companies whose shares are owned by the majority of Muslims. Corporate zakat can be given to desired mustahik throughout Indonesia, unless amil must not get the right

\footnotetext{
${ }^{26}$ Ibid.
} 
of amil zakat, but may ask for wages for the activities it performs".

In 20196 business entities pay zakat through BAZNAS Bengkulu Province amounting to $\mathrm{Rp} 86,671,577$,- (eighty-six million six hundred and seventy-one thousand five hundred and seventy-seven rupiah) and in 2020 there were 7 business entities that pay zakat through BAZNAS Bengkulu Province amounting to Rp79,150,000,- (seventy-nine million one hundred and fifty thousand rupiah). ${ }^{27}$

At least the collection of individual zakat non ASN and zakat business entities is because the Zakat Management Law is only voluntary on the self-awareness of each. ${ }^{28}$ Although the payment of individual zakat and zakat business entities has been facilitated through the services provided by BAZNAS Province such as through atm accounts, shopee pay, link aja and zakat pick-up services, but if muzaki selfawareness does not know the obligation to pay zakat, then the amount of zakat collection that exists will tend to stagnate and challenging to achieve the ideal goal of impacting most mustahik. Therefore, Law No. 23 of 2011 on Zakat Management needs to be updated for better payment of zakat. Eduardus Marius BO states: "The state of law is a state whose administration of government is based on law rooted in a set of normative starting points, in the form of principles that are the guidelines and criteria of government and the behavior of government officials"29.

${ }^{27}$ Financial reports of BAZNAS Provini Bengkulu, op.cit.

${ }^{28}$ Budi Rahmat Hakim, "Analisis Terhadap UnandgUnandg Nomor 23 Tahun 2011 tentang Pengelolaan Zakat (Perspektif Hukum Islam), Syariah : Jurnal Hukum and Pemikiran Vol. 17 No. 1 Juni 2017 diakses dari http://jurnal.uin-antasari.ac.id/index.php/syariah/article/ view/552.

29 Eduardus Marius BO, Teori Negara Hukum \& Kedaulatan Rakyat, (Jawa Timur: Setara Press, 2019), p. 328.
Indonesia as a legal country should update the Zakat Management Law to improve muzaki discipline in paying zakat. Because until now the muzaki mindset still considers zakat voluntary as stipulated in the Zakat Management Law, while in the Qur'an and Hadith has stated that zakat is an obligation for muzaki who has qualified mandatory zakat.

If the government succeeds in updating the Zakat Management Law which was initially voluntary into an obligation, of course this will have a good impact on the enactment of Islamic law in Indonesia. The impact of this renewal shows that the government supports zakat obligations by the Qur'an and Hadith.

\section{Distribution of Zakat in BAZNAS Bengkulu Province}

The process of distributing zakat in BAZNAS Bengkulu Province is divided into 3 stages: planning, coordinating, and implementation. At the planning stage baznas Bengkulu province seeks to optimize the distribution and utilization of zakat by forming 6 main work programs, namely:

1. Bengkulu Makmur is a productive assistance for mustahik, in the form of business capital and business equipment.

2. Bengkulu Cerdas is a program to distribute assistance to improve the quality and quantity of original learners from underprivileged families by providing scholarships, educational assistance, and school building surgical assistance.

3. Bengkulu Sehat is a program for the poor to get a health care program in the form of bpjs health payment assistance, medical expenses, and medical aid.

4. Bengkulu Taqwa is a distribution of assistance shown to grow the faith and piety of the community. 
5. Bengkulu Care for Poverty and Humanity is a form of concern for the poor in the form of cost of living assistance, humanitarian care, home surgery, orphanage assistance, and sembako assistance.

6. Bengkulu Move $\mathrm{On}$ is devoted in the form of concern for Kampung Zakat/ Zakat Comunnity Development (ZCD) by developing 4 aspects namely economic, health, education, and religious.

At the coordinating stage of zakat distribution in BAZNAS Bengkulu Province, it is carried out to all regions in Bengkulu Province, namely 9 (nine) districts and 1 (one) city. Distribution between BAZNAS Province and BAZNAS Regency/City is carried out in an organized manner. BAZNAS Regency/City distributes zakat to low-income families actively to the village, RT, and RW while BAZNAS Province distributes zakat passively according to mustahik request. BAZNAS Kota Bengkulu provides educational assistance to Elementary School (SD) and Junior High School (SMP) while BAZNAS Province distributes zakat to High School (SMA) and Higher Education (PT). So that there is no distribution that is overlapping, BAZNAS Province and BAZNAS Regency/City ask for information to prospective zakat recipients that they have not received zakat from BAZNAS Province and BAZNAS Regency/City before.

Distribution between BAZNAS Province and Amil Zakat Institution (LAZ) in Bengkulu Province is carried out in an organized manner. All distributions carried out by LAZ were discussed together at the Regional Coordination Meeting (Rakorda) in Bengkulu Province to evaluate the distribution of zakat that has been done. The coordination carried out by BAZNAS bengkulu province aims to distribute zakat fairly and evenly and benefit most mustahik in Bengkulu Province. The distribution used by BAZNAS Bengkulu
Province is divided into 2 categories, namely distribution and utilization. The distribution of zakat is consumptive, meaning the distribution of zakat to meet daily life mustahik such as eating, clothing, or other primary needs. As stipulated in Article 27 paragraph (2) of Law No. 23 of 2011 reads:

"Basic needs mustahik include food needs, clothing, housing, education, and health".

The distribution of consumptive zakat does not educate mustahik because it can only be used once or consumable. ${ }^{30}$ The distribution of consumptive zakat carried out by BAZNAS Bengkulu Province was carried out based on mustahik's application to BAZNAS Bengkulu Province, the application was included in the section "Assistance from the poor, poor, elderly, treatment, BPJS Health payments, purchase of medical devices, home surgery, and converts".

For muzaki who is classified as poor and poor to meet the basic needs of his life, the process of disbursement of zakat funds faster can even be liquid on the same day when the mustahik comes to the baznas provincial office, as stated by Debby as the Facilitation Staff and Social Welfare Administration of the Bengkulu Provincial Government Office, namely:

"Once there were residents from Bumi Ayu walking as far as $2 \mathrm{KM}$ to the BAZNAS Office of Bengkulu Province while carrying 2 $\mathrm{Kg}$ of gas because they did not have money to buy gas refills. This was quickly responded to by the BAZNAS board of Bengkulu Province by providing money to meet the essential cost of living. ${ }^{31}$

BAZNAS Bengkulu Province recognizes the distribution of zakat to mustahik who are

\footnotetext{
30 Afifuddin Muhajir, Zakat Produktif: Konstruksi Zakatnomics Perspektif Teoritis, Historis, and Yuridis, (Malang: CV. Literasi Nusantara Abadi, 2020), p. 155-156.

${ }^{31}$ Interviewed with Debby, op.cit.
} 
classified as poor and poor is passive, because active distribution carried out to the village, RT and RW is the duty of BAZNAS Bengkulu City. Even so, BAZNAS Bengkulu Province may distribute zakat to the poor and poor when the poor are in dire need and worthy to be helped. This distribution is included in the program "Bengkulu Peduli Poverty".

For muzaki who apply for medical assistance, BPJS payment, and purchase of medical devices will take longer in the distribution, because zakat distribution staff in BAZNAS Bengkulu Province need to conduct a survey directly and see the actual condition, after which there will be an internal meeting determining precisely whether the assistance is given. If it is on target, then the muzaki will get a call from BAZNAS Bengkulu Province regarding the timing of its distribution. This distribution is included in the "Bengkulu Sehat" program that has been launched by BAZNAS Bengkulu Province.

For muzaki who apply for home surgery will take even longer, because zakat distribution staff in BAZNAS Bengkulu Province need to conduct field and environmental surveys to determine whether or not home surgical assistance is provided. If on target, muzaki will get more information about the process and provisions of home surgery that will be carried out by BAZNAS Bengkulu Province. This distribution is included in the program "Bengkulu Peduli Kemanusiaan".

Especially the distribution of zakat in growing the faith and piety of the people of Bengkulu Province, there is no need to apply first but is a particular program that has been budgeted by BAZNAS Bengkulu Province every year. This distribution is included in the program "Bengkulu Taqwa".

The distribution of zakat is consumptive conducted by BAZNAS Bengkulu Province has been in accordance with Article 26 of Law No. 23 of 2011 states:

"The distribution of zakat, as referred to in Article 25, is carried out on the basis of priority scale with regard to the principles of equality, justice, and territoriality".

BAZNAS Bengkulu Province has distributed zakat distribution in accordance with the priority scale about the principles of equality, justice, and territoriality. The priority scale that BAZNAS has done in Bengkulu Province by prioritizing the distribution of zakat to the poor and poor who need it in a fast time and on the same day when the poor and poor come to the Provincial BAZNAS Office, even during the Covid-19 pandemic, BAZNAS Bengkulu Province does not wait for a request from mustahik but makes a particular program on the provision of sembako to people in need.

BAZNAS Bengkulu Province in isting zakat is not focused on the poor and poor, but other muzaki who are in need such as medical assistance, medical devices, to home assistance also get it. This distribution is solely to provide justice and benefits for every muzaki in need in Bengkulu Province. The distribution of zakat also includes salaries to zakat earners every month and other zakatreducing expenses such as operational funds of distribution, financial rights of amil magang, eid al-Fitr holiday allowances, health benefits, training costs of internal meetings and many more. The amount of funds issued in 2019 amounted to Rp. 516,817,321,- (9.5\% of the total zakat collected) and in 2020 amounted to Rp. $677,463,711,-(12 \%$ of the total zakat collected). ${ }^{32}$

Based on the description of the percentage of zakat amil, it is seen that the distribution of zakat carried out by BAZNAS bengkulu

32 Financial reports of BAZNAS Provinsi Bengkulu in 2019 and 2020 
province to the amil has been done as stipulated in Article 8 paragraph (1) of the National Amil Zakat Agency Regulation No. 1 of 2016 states that amil (zakat desertion) most uses zakat funds amounting to oneeighth $(1 / 8)$ or 12.5 percent of the amount of zakat funds collected.

Utilization is the distribution of zakat is productive to develop or improve the quality of life mustahik, in the form of business capital provision, existing business development or the development of specific skills ${ }^{33}$. In principle, the distribution of productive zakat is done so that mustahik can become muzaki. Such changes can occur when mustahik is allowed to manage a business or a particular skill that is further expected to change the life of the next mustahik, as stipulated in Article 27 paragraph (1) of Law No. 23 of 2011 reads: "what is meant by productive business is a business that is able to increase income, standard of living, and welfare of the community.

The distribution of productive zakat carried out by BAZNAS Bengkulu Province is based on mustahik requests to BAZNAS Bengkulu Province. For muzaki who request business development, the application is studied first by the channeling staff and directly surveying the business location. After that, the channeling staff and vice chairman of the distribution field conducted an internal meeting to determine whether zakat was distributed. Until 2019, the distribution of zakat for business development is done by giving business capital in the form of money. However, after that the distribution of zakat in the form of money is no longer allowed but in the form of the provision of business tools, business premises, and business materials. The provision of assistance aims to keep the mustahik business continues, while if given money, muzaki can use it for other

\footnotetext{
${ }^{33}$ Affifuddin Muhajir, op.cit, p. 35.
}

purposes. This distribution is included in the program "Bengkulu Makmur".

For muzaki who make a request for educational assistance, the application is studied first by the distribution staff and directly survey the location of the residence. After that, the channeling staff and vice chairman of the distribution field conducted an internal meeting for the determination of whether zakat was distributed. Educational assistance provided by BAZNAS Bengkulu Province is further divided into scholarships, school teacher assistance, and school building surgery. This distribution is included in the program "Bengkulu Cerdas".

Especially the distribution of zakat in empowering the village community, there is no need to apply first but is a unique program that has been budgeted by BAZNAS bengkulu province since 2019. This distribution is included in the "Be-ngkulu Move On" program, in the implementation of the Bengkulu Move On program in collaboration with existing Amil Zakat Institutions (LAZ) such as LAZIZNU Bengkulu Branch, Baitul Maal Bengkulu Branch, and Dompet Duafa Bengkulu Province. ${ }^{34}$

The implementation of zakat distribution is productive conducted by BAZNAS Bengkulu Province in accordance with Article 27 of Law No. 23 of 2011 states:

1. Zakat can be used for productive efforts in the framework of handling low-income families and the quality of the people.

2. The utilization of zakat for productive efforts as referred to in paragraph (1) is done when the basic needs mustahik have been met.

The distribution of productive zakat becomes a more recommended program in BAZNAS

${ }^{34}$ Interviewed with Bunafi, ibid. 
Bengkulu Province, but the distribution of productive zakat is carried out after the fulfillment of muzaki immediate basic needs first. This can be seen from the zakat distribution report in BAZNAS bengkulu province in 2019 and 2020 more distributed to the poor and poor with the following table information:

Table 2. Distribution of Zakat in BAZNAS Bengkulu Province in 2019

\begin{tabular}{llr}
\hline No. & \multicolumn{1}{c}{ Asnaf } & \multicolumn{1}{c}{ Total } \\
\hline 1. & $\begin{array}{l}\text { Distribution of Zakat Funds to the } \\
\text { Poor and Poor }\end{array}$ & 3.238 .054 .900 \\
\hline 2. & Distribution of Zakat Funds for Amil & 516.817 .321 \\
\hline 3. & $\begin{array}{l}\text { Distribution of Zakat Funds for } \\
\text { Muallaf }\end{array}$ & 5.300 .000 \\
\hline 4. & $\begin{array}{l}\text { Distribution of Zakat Funds for } \\
\text { Riqab }\end{array}$ \\
\hline 5. & $\begin{array}{l}\text { Distribution of Zakat Funds for } \\
\text { Gharim }\end{array}$ \\
\hline 6. & $\begin{array}{l}\text { Distribution of Zakat Funds for } \\
\text { Fisabilillah }\end{array}$ \\
\hline 7. & $\begin{array}{l}\text { Distribution of Zakat Funds for Ibnu } \\
\text { Sabil }\end{array}$ \\
\hline 8. & $\begin{array}{l}\text { Distribution of Zakat Funds for } \\
\text { Others }\end{array}$ \\
\hline Level of effectiveness of distribution & 5.625 .000 .000 \\
\hline
\end{tabular}

Source: BAZNAS Financial Report of Bengkulu Province in 2019

Table 3. Distribution of Zakat in BAZNAS Bengkulu Province in 2020

\begin{tabular}{llr}
\hline No. & \multicolumn{1}{c}{ Asnaf } & \multicolumn{1}{c}{ Total } \\
\hline 1. & $\begin{array}{l}\text { Distribution of Zakat Funds to the } \\
\text { Poor and Poor }\end{array}$ & 3.302 .981 .950 \\
\hline 2. & Distribution of Zakat Funds for Amil & 677.463 .711 \\
\hline 3. & $\begin{array}{l}\text { Distribution of Zakat Funds for } \\
\text { Muallaf }\end{array}$ & 1.100 .000 \\
\hline 4. & Distribution of Zakat Funds for Riqab & \\
\hline 5. & $\begin{array}{l}\text { Distribution of Zakat Funds for } \\
\text { Gharim }\end{array}$ & 5.000 .000 \\
\hline 6. & $\begin{array}{l}\text { Distribution of Zakat Funds for } \\
\text { Fisabilillah }\end{array}$ & 766.300 .200 \\
\hline 7. & $\begin{array}{l}\text { Distribution of Zakat Funds for Ibnu } \\
\text { Sabil }\end{array}$ & 2.400 .000 \\
\hline 8. & $\begin{array}{l}\text { Distribution of Zakat Funds for } \\
\text { Others }\end{array}$ \\
\hline Level of effectiveness of distribution & 535.731 .413 \\
\hline
\end{tabular}

Source: BAZNAS Financial Report of Bengkulu Province in 2020
Based on the zakat distribution table in 2019 and 2020, the distribution of zakat to the poor and poor becomes the priority. The second priority in the distribution of zakat is amil zakat and many more. The eight distributions of zakat are consumptive unless the distribution carried out to the poor and poor is divided into 2 two consumptive and productive. The percentage of distribution effectiveness in 2019 amounted to $71 \%$ and the percentage of distribution in 2020 amounted to $74 \%$. Meanwhile, the rest of the zakat funds that BAZNAS Bengkulu Province does not channel are stored in the form of savings in the bank. When necessary in emergencies and urgent, such as natural disasters and other circumstances, BAZNAS can distribute these funds immediately. ${ }^{35}$

The percentage of zakat distribution below $85 \%$ has not been considered as a good zakat distribution. Although the effectiveness of zakat distribution in BAZNAS Bengkulu Province has not reached $85 \%$, but the distribution of zakat carried out by BAZNAS Bengkulu Province is more widely distributed to the poor and poor. ${ }^{36}$ This explains that BAZNAS Bengkulu Province in distributing zakat prioritizes the benefits and the poor, only then the rest of mustahik. The theory of distributive justice states that fair it gives by its needs, so that the poor and poor must take precedence in the distribution of zakat. E. Sumaryono states:

"Distributive justice refers to the distribution of goods and services to each person according to his position in society and the equality before the law." 37

Mustahik will receive zakat according to his circumstances, the heavier his life will be the more zakat he should receive. Mustahik who

\footnotetext{
${ }^{35}$ Interviewed with Bunafi, ibid.

${ }^{36}$ Interviewed with Bunafi, ibid.

${ }^{37}$ E. Sumaryono, Etika and Hukum: Relevansi Teori
} Hukum Kodrat Thomas Aquinas, (Yogyakarta: Kanisius), p. 92. 
has 8 children will get more zakat funds than mustahik who has 2 children only.

The distribution of zakat carried out by BAZNAS Bengkulu Province has helped many existing mustahik, not only to meet basic needs. BAZNAS Bengkulu Province also helps mustahik for a better life such as scholarships, school surgery, and business capital. The assistance provided by BAZNAS bengkulu province as an effort to ease the burden that is being experienced mustahik, if this distribution continues to be improved, the hope of the creation of justice and welfare of the community in Bengkulu Province insyallah can be achieved in the future.

\section{Supervision of Zakat Management against BAZNAS Bengkulu Province}

This supervision aims to find out and fix the weaknesses in BAZNAS Bengkulu Province. The implementation of zakat management supervision in BAZNAS Bengkulu Province is carried out internally and externally. ${ }^{38}$ Internal supervision including preventive supervision to prevent the occurrence of abuses and irregularities in zakat management in BAZNAS Bengkulu Province is carried out by the Deputy Chairman of BAZNAS Province to his staff, namely:

\section{Head of Administration:}

Bunafi, S.P.

\section{Collecting Staff:}

Bambang Hermant, A.Md.

\section{Distributing Staff:}

Junaidi, S.E.

\section{Financial Staff:}

1. Indah Purnama, S.E.

2. Rama Doni, S.E.I.

\footnotetext{
${ }^{38}$ Kementerian Agama, Pedoman Pengawasan Lembaga Pengelola Zakat, (Kementerian Agama, Direktorat Jenderal Bombingan Masyarakat Islam: Direktorat Pemberdayaan Zakat, 2012), p. 16.
}

The Vice Chairman is authorized to oversee the duties that his staff has carried out, Vice Chairman I is in charge of overseeing the field of collection, Vice Chairman II is in charge of overseeing the distribution field, and Vice Chairman III is in charge of overseeing the financial field. In the end, thorough supervision was carried out by the Chairman of BAZNAS Bengkulu Province. ${ }^{39}$

Internal supervision by the Deputy Chairman of BAZNAS Bengkulu Province on his staff is not carried out routinely. In order to solve the problems faced technically and suddenly, the staff is assisted by the Head of Business who is authorized to coordinate all activities carried out by the three staff below. ${ }^{40}$ The Vice Chairman of BAZNAS in their respective fields is also supervised thoroughly by the Chairman of BAZNAS Bengkulu Province by holding meetings every six months or every time needed. Because, all policies carried out in BAZNAS Bengkulu Province are accountable to the Chairman of BAZNAS Bengkulu Province. ${ }^{41}$

Unfortunately, the internal supervision carried out by the Chairman of BAZNAS bengkulu province was not followed by supervision by the Supervisory Board. When viewed from the Decree of the Appointment of baznas chairman of Bengkulu province, the highest position is the chairman of BAZNAS Province. No party has the right to supervise internally on what policies have been taken by the Chairman of BAZNAS.

The Supervisory Board is needed to ensure that the internal supervision of zakat management that the Chairman of BAZNAS Province has carried out is managed transparently and can be accounted for. In fact, when there are signs of abuse, the Supervisory

\footnotetext{
${ }^{39}$ Interviewed with Bunafi, op.cit

${ }^{40}$ Interviewed with Bunafi, Ibid.

${ }^{41}$ Ibid.
} 
Board can quickly give advice to the Chairman of BAZNAS to resolve it.

Although there is no oversight of the Chairman of BAZNAS Province that should be carried out by the Supervisory Board. Supervision of the Chairman of BAZNAS Bengkulu Province is assisted by BAZNAS Pusat by providing zakat management accountability reports through the BAZNAS Information Management System (SiMBA) application that can be filled at any time and integrated into the CENTRAL BAZNAS.

Furthermore, external supervision of zakat management in BAZNAS Bengkulu Province is carried out by the Regional Government of Bengkulu Province, the Ministry of Religious Affairs of the Republic of Indonesia, Public Accountants, and the Community.

1. Supervision of the Regional Government of Bengkulu Province. This is based on Article 34 paragraph 2 of Law No. 23 of 2011 reads:

"Governors and regents/mayors carry out the construction and supervision of BAZNAS Province, BAZNAS Regency/City, and LAZ according to their authority".

During 2019 and 2020 there was no construction and supervision carried out by the Governor to BAZNAS bengkulu province. The indifference of the Head of Daer-ah of Bengkulu Province to the construction and supervision of zakat management is due to the lack of understanding of the Regional Head of Bengkulu Province of the supervisory obligations that should be carried out, as stated by Debby as the Facilitation Staff and Social Welfare Administration, namely the Provincial Government is just waiting for the zakat management report from BAZNAS Bengkulu Province. However, since 2016 BAZNAS Bengkulu Province has never reported the management of zakat. ${ }^{42}$

\footnotetext{
${ }^{42}$ Interviewed with Debby, op.cit.
}

The provincial government is only waiting for the zakat management report from BAZNAS Bengkulu Province, even though the Bengkulu Provincial is based on Article 34 paragraph 2 of the Zakat Management Law Government may provide a warning letter and even force BAZNAS Bengkulu Province to provide a zakat management report. ${ }^{43}$

Since the establishment of BAZNAS Bengkulu Province, BAZNAS Bengkulu Province has never received operational funding assistance from APBD. There are operational rights that BAZNAS Bengkulu Province should receive as in Article 31 of Law No. 23 of 2011 on Zakat Management, which reads:

1. In carrying out its duties, BAZNAS Province and BAZNAS Regency/City as referred to in Article 16 paragraph (1) are financed with the Regional Revenue and Spending Budget and Amil Rights.

2. In addition to financing as mentioned in paragraph (1) BAZNAS Province and BAZNAS Regency/City can be financed with The State Revenue and Expenditure Budget.

Article 31 paragraph (1) of Law No. 23 of 2011 on Zakat Management explains that there are rights that BAZNAS Province should receive in the form of APBD funds to carry out zakat operations such as zakat cars, printers, paper, and other operational needs. The Ministry of Home Affairs (Ministry of Home Affairs) has also issued a letter of appeal to all Governors number 420.12/4456/SJ on August 20, 2021 to allocate APBD for zakat management operations in BAZNAS Province.

In 2019 and 2020, BAZNAS Bengkulu Province never received operational funds

\footnotetext{
${ }^{43}$ Interviewed with Bunafi, op.cit.
} 
from APBD through the Bengkulu Provincial Government. However, in 2019, for the first time BAZNAS Bengkulu Province received operational funding assistance from the State Budget through the Ministry of Religious Affairs of 100 million rupiah. However, in 2020 BAZNAS Bengkulu Province did not get operational funding assistance anymore. ${ }^{44}$

BAZNAS Bengkulu Province admits to having a less harmonious relationship with the Bengkulu Provincial Government, because the operational funds submitted by BAZNAS are never reviewed but every activity carried out by BAZNAS Province in collaboration with the Bengkulu Provincial Government, instead the activity is recognized by the activities initiated by the Provincial Government itself. ${ }^{45}$

\section{Supervision of the Ministry of Religious Affairs of the Republic of Indonesia}

Supervision of sharia audit conducted by the Ministry of Religious Affairs of the Republic of Indonesia based on Article 75 paragraph 2 of Government Regulation No. 14 of 2014 reads: "Sharia audit as referred to in paragraph (1) is carried out by the ministry that organizes government affairs in the field of religion".

Then strengthened by Article 34 paragraph 2 of Law No. 23 of 2011 reads: "The Minister carries out the construction and staffing of BAZNAS, BAZNAS Province, BAZNAS Regency/City, and LAZ".

During 2019 and 2020, the Central Ministry of Religious Affairs routinely conducts sharia audits every year to BAZNAS bengkulu province. Sharia audit examines whether the distribution carried out by BAZNAS Province is following sharia principles as stipulated

${ }^{44}$ Financial reports of pengelolaan zakat tahun 2019, op.cit.

${ }^{45}$ Interviewed with Bunafi, op.cit in Surat At-Taubah paragraph 60 which consists of 8 asnaf. In 2019 and 2020, there are no deviations in the distribution of zakat carried out by BAZNAS Bengkulu Province, meaning that BAZNAS bengkulu province has distributed zakat to 8 asnaf, Except for the distribution to slaves who no longer exist.

\section{Supervision of Public Accountants}

Supervision of zakat financial management statements conducted by Public Accountants based on Article 75 paragraph 3 of Government Regulation No. 14 of 2014 reads:

Public accountants conduct financial audit as referred to in paragraph (1).

Public accountants are in charge of overseeing whether the fund management report made by BAZNAS Province follows the principles of fund management in general and assess whether there is a misappropriation of funds by BAZNAS Bengkulu Province.

Since BAZNAS Bengkulu Province was established until 2019, it has never been supervised by public accountants. Only in 2020 the financial management report of BAZNAS zakat bengkulu province has been supervised by public accountants services. The results of supervision of zakat financial management conducted by public accountants in 2020 provide "reasonable without exception" to BAZNAS Bengkulu Province meaning that zakat financial management conducted by BAZNAS Province is carried out healthily and there is no misappropriation of funds. ${ }^{46}$

\section{Pengawasan Masyarakat}

Public supervision of BAZNAS bengkulu province based on Article 35 paragraph 3 of Law No. 23 of 2011, reads:

46 Laporan Pengelolaan Zakat BAZNAS Provinsi Bengkulu tahun 2020. 
Public supervision of BAZNAS and LAZ in the form of:

a. Access to information about zakat management conducted by BAZNAS and LAZ.

b. Delivery of information in case of irregularities in zakat management carried out by BAZNAS and LAZ.

In order to make it easier for people to get information collected and distributed zakat in BAZNAS Bengkulu Province, BAZNAS posts its complete activities on instagram social media @baznas_provinsi every time has been carried out the collection and distribution of zakat. In addition, every 6 months after the evaluation meeting of zakat funds, BAZNAS Bengkulu Province seeks to issue the amount of funds collected and channeled through the Bengkulu Radar Newspaper. ${ }^{47}$

Reports to the community are needed to maintain the trust of muzaki who has distributed zakat through BAZNAS Bengkulu Province. If muzaki trust is well maintained, it is expected that muzaki can invite his family, relatives, and friends to pay zakat to BAZNAS Bengkulu Province. Eventually, more mustahik feel the impact of the impact zakat.

External supervision is repressive supervision after the implementation of zakat management by BAZNAS Bengkulu Province. Supervision carried out by outside parties, to ensure the management of zakat that BAZNAS Bengkulu Province has carried out by sharia audits and financial audits. ${ }^{48}$

Sharia audit aims to ensure the distribution of zakat in BAZNAS Bengkulu Province following Surat At-Taubah verse 60 consists of 8 asnaf namely fakir, poor, zakat manager

\footnotetext{
${ }^{47}$ Interviewed with Bunafi, op.cit.

${ }^{48}$ Kementerian Agama, Pedoman Pengawasan Lembaga Pengelola Zakat, op.cit, p. 39.
}

(amil), muallaf, to free slaves (riqab), people who are in debt (gharimin), to be in the way of Allah Swt (fi sabilillah), and those who are on the Way (Ibn Sabil). Based on the results of sharia audits conducted by the Ministry of Religious Affairs, the Indonesian Ministry of Religious Affairs has stated that the distribution of zakat carried out by BAZNAS of Bengkulu Province in 2019 and 2020 has been by sharia provisions.

Public accountants and local governments carry out financial audits. However, the monitoring of financial statements in BAZNAS Province was first supervised by public accountants in 2020 while the Regional Government of Bengkulu Province until now has never supervised the financial management of zakat on baznas financial statements of Bengkulu Province. Supervision of financial statements against BAZNAS of Bengkulu Province needs to be strengthened by the Provincial Government to further crack down on misappropriation of funds if found by public accountants. Supervision from the Local Government aims to maximize the collection and distribution of zakat to all communities in Bengkulu Province.

Supervision of zakat management carried out on BAZNAS Bengkulu Province aims to provide benefits and happiness to as many muzaki and mustahik as possible. Muhammad Erwin quotes Jeremy Bentham as saying: ${ }^{49}$

To realize the happiness of individuals and society, the legislation must achieve four goals, namely to Provide Subsitence (to provide a living), to Provide Abdundance (to provide abundant food), to Provide Security (to provide protection), to Attain Equity (to achieve equality).

49 Muh. Erwin, Filsafat Hukum ; Refleksi Kritis Terhadap Hukum, (Jakarta: Rajawali Press, 2011), p. 180-181. 
For mustahik, legal protection in the form of the receipt of zakat funds by his needs, while for muzaki legal protection in the form of zakat distribution to mustahik in need. The expediency theory aims to provide a sense of security and maintain muzaki's trust to continue distributing zakat through BAZNAS Bengkulu Province.

\section{Conclusion}

From the previous explanation it can be concluded:

1. The planning stage of zakat collection in BAZNAS Bengkulu Province is not done with a particular strategy and is not fixated on a specific schedule. The stage of coordinating zakat collection in BAZNAS Bengkulu Province is done directly by depositing zakat money directly to the Provincial BAZNAS office or through zakat pick-up media that has been provided, and indirectly through zakat collection unit (UPZ), bank account, and other payment methods such as ovo, link aja, gopay, and shopee pay. As for the implementation of zakat collection of property sourced from individual zakat and zakat business entities.

2. The distribution of zakat property in BAZNAS Bengkulu Province is carried out with 3 stages: planning, coordinating, and implementing. The planning stage by forming 6 main work programs, namely Bengkulu Makmur, Bengkulu Cerdas, Bengkulu Sehat, Bengkulu Taqwa, Bengkulu Peduli Poverty and Humanity, and Bengkulu Move On. The coordination stage was carried out by holding a Regional Coordination Meeting (Rakorda) attended by BAZNAS from 9 Districts and 1 City and Amil Zakat Institution (LAZ) in Bengkulu Province. The implementation stage is divided into 2 categories: the distribution of zakat, which is consumptive, and the utilization of productive zakat. The distribution of consumptive zakat is distributed to the poor, poor, elderly, treatment, BPJS Health payments, purchase of medical devices, home surgery, and converts. While the distribution of productive zakat is channeled through zmart $\&$ bedah warung, business tool assistance, high school education assistance/equivalent \& Higher Education.

3. Supervision of zakat management of BAZNAS Bengkulu Province is carried out internally and externally. (1). The head of BAZNAS Bengkulu Province carries out internal supervision to his staff, but no Supervisory Board should oversee the baznas leadership (2). External supervision is carried out by the Ministry of Religious Affairs of the Republic of Indonesia, Public Accountants, and the public. However, the Bengkulu Provincial Government does not conduct supervision to BAZNAS bengkulu province. Therefore, BAZNAS Bengkulu Province needs to carry out measurable and strategic planning in the collection of zakat. The Regional Government of Bengkulu Province must more firmly monitor the performance of BAZNAS Bengkulu Province, both against its staff and baznas leadership by utilizing the services of kredible public accountants.

\section{References}

Afiyana, Indria Fitri. "Tantangan Pengelolaan Dana Zakat di Indonesia dan Literasi Zakat" Jurnal Akutansi dan Keuangan, Vol. 16. No. 2 Tahun 2019 diakses dari http://journal. feb.unmul.ac.id/index.php/AKUNTABEL/ article/view/6013/610.

Atabik, Ahmad. "Manajemen Pengelolaan Zakat Yang Efektif di Era Komtemporer", ZISWAF Jurnal Zakat dan Wakaf, Vol. 2, No. 1 (2016). 
Erwin, Muh. Filsafat Hukum; Refleksi Kritis Terhadap Hukum, Jakarta: Rajawali Press, 2011.

Hakim, Budi Rahmat. "Analisis Terhadap Undang-Undang Nomor 23 Tahun 2011 tentang Pengelolaan Zakat (Perspektif Hukum Islam)", Syariah : Jurnal Hukum dan Pemikiran Vol. 17 No. 1 Juni 2017, diakses dari http://jurnal.uin-antasari.ac.id/ index. php/syariah/article/view/552.

Hasanah, Uswatun. "Optimalisasi Pengelolaan Zakat Produktif Sebagai Realisasi Revolusi Mental", IJTIMAIYYA, Vol. 13, No. 1 (2020).

Hidajat, Rachmat. "Penerapan Manajemen Zakat Produktif dalam Meningkatkan Ekonomi Umat di PKPU (Pos Keadilan Peduli Umat) Kota Makasar" Jurnal Studi Agama, Vol. XVII, No.1, Tahun 2017 diakses dari https:// journal.uii.ac.id/Millah/article/view/10049.

Interviewed with Bunafi as Kepala Pelaksana Baznas Provinsi pukul 14.00 tanggal 19 Januari 2021.

Interviewed with Reva as Bidang Penghimpunan IZI Perwakilan Bengkulu pukul 11.00 tanggal 29 Mei 2021.

Interviewed with Septi as Sekretaris Penaizawa Kanwil Kemenag Provinsi Bengkulu pukul 13.00 tanggal 30 April 2021.

Interviewed with Supardi Jaiz as Ketua UPZ UIN Fatmawati Soekarno Bengkulu pukul 08.00 tanggal 22 April 2021.

Interviewed with Wiryono as Ketua UPZ Universitas Bengkulu Bengkulu pukul 11.00 tanggal 24 April 2021.

Kementerian Agama, Pedoman Pengawasan Lembaga Pengelola Zakat, (Kementerian Agama, Direktorat Jenderal Bombingan Masyarakat Islam: Direktorat Pemberdayaan Zakat, 2012).

Khotib, Muhyiddin. Rekonstruksi Fikih Zakat: Telaah Komprehensif Fikih Zakat Pendekatan Teoritis dan Metodologi, Malang: CV. Literasi Nusantara Abadi, 2019.

Marius. Eduardus BO. Teori Negara Hukum \& Kedaulatan Rakyat, Jawa Timur: Setara Press, 2019.
Muhajir, Afifuddin. Zakat Produktif: Konstruksi Zakatnomics Perspektif Teoritis, Historis, dan Yuridis, Malang: CV. Literasi Nusantara Abadi, 2020.

Nurhasana, Siti. "Maksimalisasi Potensi Zakat melalui Peningkatan Kesadaran Masyarakat", Jurnal Ekonomi dan Bisnis Islam, Fakultas Ekonomi dan Bisnis Islam Universitas Islam Negeri Imam Bonjol Padang, Vol. 3. No. 2 Tahun 2018, diakses dari http://journal. febi.uinib.ac.id/index.php/jebi/article/ view/177/197.

Nurhayati, Sri. Akutansi dan Manajemen Zakat, Jakarta Selatan: Salemba Empat, 2019.

Permana, Agus, Ahmad Baehaqi, "Manajemen Pengelolaan Lembaga Amil Zakat Dengan Prinsip Good Governance", AL-MASRAF Jurnal Keuangan dan Perbankan, Vol. 3, No. 2 (2018).

Purnomo, Herdaru. "Top Pak Jokowi! Perangi Kemiskinan Ekstrem, RI Masuk 15 Besar", diakses tanggal 25 Februari 2021 dari https://www.cnbcindonesia.com/news/ 20191119085453-4-116192/top-pakjokowi-perangi-kemiskinan-ekstrem-rimasuk-15-besar/2.

Septiarini, Dina Fitrisia. "Pengaruh Transparansi dan Akuntabilitas terhadap Pengumpulan Dana Zakat, Infaq dan Shadaqah pada LAZ di Surabaya”, Jurnal Akutansi Universitas Negeri Surabaya (2011), Vol 2, No 2, diakses tanggal 23 Februari 2021 dari https://journal. unesa.ac.id/index.php/aj/article/view/268.

Sumaryono, E. Etika dan Hukum: Relevansi Teori Hukum Kodrat Thomas Aquinas, Yogyakarta: Kanisius, 2002.

Susilowati, Dewi, Christina Tri Setyorini. "Efektivitas Tata Kelola Dana Zakat", Jurnal Akuntansi Multi Paradigma, Vol 9, No 2 (2018)

Syafiq, Ahmad. "Urgensi Peningkatan Akuntabilitas Pengelola Zakat", ZISWAF Jurnal Zakatdan Wakaf, Vol. 3, No. 1 (2016).

Syafe'i, Ermi Suhasti. Mengoptimalkan Potensi Zakat, Yogyakarta: (P3EI) UII, 2002. 